\title{
Positive Yield Impact of Predacious Mites in Tea Production Areas of Kenya
}

\author{
Daniel L. Mutisya ${ }^{1}$, E. M. El Banhawy ${ }^{2} \&$ Evelyn C. R. Cheramgoi $^{3}$ \\ ${ }^{1}$ Kenya Agricultural \& Livestock Research Organization (KALRO)-Agricultural Mechanization \\ Institute-Katumani, P.O. Box 340-90100. Machakos, Kenya \\ ${ }^{2}$ University of Nairobi. P. O. Box 30197-00100. Nairobi, Kenya \\ ${ }^{3}$ KALRO -Tea Research Institute. P.O. Box 820-20200. Kericho, Kenya \\ Correspondence: Daniel L. Mutisya, KALRO-Agricultural Mechanization Institute-Katumani, P.O. Box \\ 340-90100. Machakos, Kenya. E-mail: dlmutisya@gmail.com/daniel.mutisya@kalro.org
}

\author{
Received: January 25, 2018 Accepted: February 9, 2018 Online Published: April 26, 2018 \\ doi:10.5539/sar.v7n3p1 URL: https://doi.org/10.5539/sar.v7n3p1
}

\begin{abstract}
Tea agro ecosystems are least disturbed in comparison to other crop systems due to the plant canopy type. A survey on predacious mites' abundance and impact on leaf yield in different tea production areas was carried out in 2014-2015 in Kenya. Major pest species were the red spider mite Oligonychus coffeae and the yellow thrip, Scirtothrips dorsalis. The red crevice mite, Brevipalpus phoenicis was found in few areas and in low numbers. Predacious mites of Phytoseiidae Family were highest at 5.8 and 6.8 mites per sample during dry and wet seasons, respectively. Phytoseiid abundance during the dry and wet seasons did not differ much within most sample sites. Presence of phytoseiid mites in combination with NPK-fertilizer-high altitude led to the strongest correlation to leaf yield than any other combination variable. High phytoseiid density- high altitude was third with positive impact to yield increase after high altitude combined with NPK-fertilizer. The findings here show contributory positive impact of phytoseiids in tea leaf yield in an agro eco-system.
\end{abstract}

Keywords: ecosystem, yield, impact, NPK-fertilizer, altitude

\section{Introduction}

Tea, Camellia sinensis (L) O. Kuntze, is one of the most inexpensive popular beverages in the world. Tea beverage is prepared from the tender leaves and buds of $C$. sinensis, which is a woody perennial plantation crop cultivated as a monoculture on large and small holdings. World main tea producers are India, Sri Lanka and China, with Indonesia, Japan, Kenya, Malawi, Uganda, Georgia, Turkey, Iran and Argentina (FAOSTAT 2016). Other minor producers are Vietnam, Mozambique, Tanzania and Democratic Republic of Congo. The tea plant has unique characteristics which influence its pest ecology in a very special way (Roy et al. 2014). Tea plantations are usually evergreen, comprising of either one cultivar of the world six varieties or genetically diverse clone cultivars (FAO 2015; Majumder et al. 2010). In some cases, some cultivars yield higher leaf than others in specific conditions of temperature and altitude (Jayakrishnan \& Ramani 2015). The varied ecological requirement of the crop range from $0-2000 \mathrm{~m}$ above sea level in the Asia continent while in Africa tea is only produced in the high altitude areas of the tropical climate (Majumder et al. 2010). Tea crop near the equator produces almost the same yield in relation to cultivar potential (FAO 2015). In Kenya the crop occupies the most arable land and is the number one foreign earner in economic terms with world volume supply of $8 \%$ of 432,400 metric tons (FAOSTAT 2016; Maity \& Ghosh 2015). Worldwide tea crop suffers from attack by a number of pests and pathogens, causing significant yield losses (Jepson et al. 1975; Muraleeedharan et al. 2015). However, detailed information on pest abundance and production practices in Kenya have not been closely analyzed to reflect the actual biotic production constraints. Whether the Kenya tea agro-ecosystems are stable or need some modification in the prevailing environmental conditions could be assessed before decision on management option of the target pest.

Worldwide, the major pests of tea plant include the mite species, Oligonychus coffeae Nietner (Acari: Tetranychidae) that lowers leaf quality and yield in plantations (Roy et al. 2014a). Coupled with other pests like plant bugs and thrips the leaf quality and continuous rejuvenation goes down (Roy et al. 2014). Other small-sized 
mites are Acaphylla theae Watt (Eriophyidae) and Calcarus carinatus Green (Eriophyidae), being common in Asia and Africa (Childers \& Achor 1999; Childers \& Rodriques 2011).

The present work focused on determining production practices by the small holder farmers and assessing what pest constraints are in Kenya's tea production systems. Rather, a diagnostic approach on what prevailed in the different production systems, with emphasis on beneficial biological agents like predacious mites and their impact on the pests and final leaf yield was what was assessed in the study survey.

\section{Materials and Methods}

\subsection{Survey Sites}

A survey was carried out to determine pest status and beneficial organism of the predacious mites in tea production areas in Kenya in 2014-2015. The areas covered included the North Rift Valley and eastern-central highlands of the country where tea plantations were established. Tea crop plots established some 20 years ago were targeted for the study which provided the highest biotic factors, as a stable agro-ecosystem. The type of production system, either monoculture or intercrop was scored as such during the sample data collection. The selected sample plots were the different production practices of the small-scale farmers who did not use chemicals pesticides.

\subsection{Pest Status}

Throughout the two-year survey, presence of major pests was analyzed for their abundance on the impact on leaf yield in the production systems at specific sites. Farmers provided data of their annual crop management operations. Care was taken to determine site pest abundance during wet and dry production seasons. Specific site environmental factors were analyzed in relation to pest status on tea crop. Information on leaf yield status were corroborated from farmer records at each site at specific conditions in the production areas. To sample for invertebrate herbivore pests, a blue plastic disc of $60 \mathrm{~cm}$-diameter was placed under plant canopy and three quick shakings carried out on three plants. With the aid of a hair camel brush, all pest specimens were collected from the plastic disc and preserved in $70 \%$ alcohol glass vials of 50ml. Later in the laboratory, spider mite specimens were separated from other specimens and identified by the second author (using identification key by El-Banhawy \& Knapp 2011).

\subsection{Analysis of Input Levels}

Tea production inputs included nitrogen-phosphorous-potassium (NPK) fertilizer which is basic for high leaf yield in the presence of rainfall showers. Farming practices like quantity of fertilizer application per year and resulting leaf yield volume at each farm were recorded. Weeding by hand implements ensured least damage of the secondary root system of plants, applied by $100 \%$ of the farmers. Regular pruning of the plant tops enabled a flat plucking table and thickened canopy providing a living shelter for beneficial organisms. An open approach of enquiring from the producers the type of pesticide use; either fungicides, herbicides or insecticide was adopted.

\subsection{Diagnosis for Beneficial Organisms}

The presence and abundance of beneficial organisms was scored. Later, the specific organisms were identified and their abundance in relation to the yield of tea leaf in the prevailing conditions scored. This enabled further analysis of the impact of the major beneficial organisms in the production sites. All observable beneficial organisms were considered for their abundance and leaf yield impact at the specific sites.

\subsection{Interactive Environment-biological Factors}

Once the biological and environmental factor data were assembled, an analysis approach was carried out to reflect site region abundance of beneficial organisms' vis-a-vis environmental conditions and regressed with yield volume for positive or negative effect. Sample units were three tea bushes per farm and at least three fields per region. Comparable altitude and farm acreage was also scored at each site. Both the major pests and abundance of predacious mites was also counted.

\subsection{Data Collection and Analyses}

Data analyses by analysis of variance (ANOVA) was carried out and Student Newman Keuls Test for means separation for significant difference on altitude, leaf yield, and production acreage in addition to fertilizer quantity as well as phytoseiid density per sample. Correlation levels of various parameters like combination of phytoseiid-altitude, fertilizer-phytoseiid-altitude among others were analyzed to determine effect to leaf yield. General Linear Model Procedure (GLM-PROC) was used to get the factual relationship of ideal conditions for healthy tea leaf production. 


\section{Results}

\subsection{Site Pest Status}

The common pests across the ten sample regions were the red spider mite, Oligonychus coffeae (Nietner), the yellow thrip, Scirtothrips dorsalis (Hood) and the crevice mite, Brevipalpus phoenicis Gijskes (Table 1). The red mite, $O$. coffeae had highest significant $(p<0.05)$ density than the other two pests in Imenti South. Narrowing down to specific regions, highest density of $O$. coffeae was at 6.8 mites per sample in Kericho, followed by Nandi Hills region at 6.3 mites /sample.

Similarly, the thrip $S$. dorsalis had highest density at 11.3 individuals per sample in Murang'a, followed by Kericho at 4.0. The least abundant pest, the red crevice mite B. phoenicis was scored at a peak of 5.0 mites per sample in Kiambu and at 4.7 mites/ sample in Nandi Hills region. The thrip, S. dorsalis was absent in Nyeri, Imenti South and Imenti North, while B. phoenicis was absent in Imenti South. Leaf brown scotching by $O$. coffeae was evident in Murang'a and Imenti South especially during the dry spell months of July to September. The thrip damage was rarely clear besides low wilting appearance of leaves during the dry spell. The low abundance of the crevice mite, $B$. phoenicis did not result to any observable plant stress from the cell-sacking herbivore.

Table 1. Major pest species on tea crop in different production regions of Kenya in 2014-2015

\begin{tabular}{|c|c|c|c|c|}
\hline Region & Major pest & Density/ sample & $F$-value & $P$-value \\
\hline \multirow[t]{3}{*}{ Imenti North } & O. coffeae & $2.0^{\mathrm{A}}$ & 1.8 & 0.2844 \\
\hline & S. dorsalis & $0.0^{\mathrm{A}}$ & & \\
\hline & B. phoenicis & $1.3^{\mathrm{A}}$ & & \\
\hline \multirow[t]{3}{*}{ Imenti South } & O. coffeae & $6.0^{\mathrm{A}}$ & 18.8 & 0.0093 \\
\hline & S. dorsalis & $0.0^{\mathrm{B}}$ & & \\
\hline & B. phoenicis & $0.0^{\mathrm{B}}$ & & \\
\hline \multirow[t]{3}{*}{ Murang’a } & O. coffeae & $4.7^{\mathrm{A}}$ & 3.0 & 0.1623 \\
\hline & S. dorsalis & $11.3^{\mathrm{A}}$ & & \\
\hline & B. phoenicis & $4.3^{\mathrm{A}}$ & & \\
\hline \multirow[t]{3}{*}{ Nakuru } & O. coffeae & $3.7^{\mathrm{A}}$ & 4.9 & 0.0840 \\
\hline & S. dorsalis & $2.7^{\mathrm{B}}$ & & \\
\hline & B. phoenicis & $0.8^{\mathrm{C}}$ & & \\
\hline \multirow[t]{3}{*}{ Mt. Elgon } & O. coffeae & $1.3^{\mathrm{A}}$ & 3.0 & 0.1600 \\
\hline & S. dorsalis & $2.3^{\mathrm{A}}$ & & \\
\hline & B. phoenicis & $1.3^{\mathrm{A}}$ & & \\
\hline \multirow[t]{3}{*}{ Nandi Hills } & O. coffeae & $6.3^{\mathrm{A}}$ & 3.4 & 0.1352 \\
\hline & S. dorsalis & $2.0^{\mathrm{A}}$ & & \\
\hline & B. phoenicis & $4.7^{\mathrm{A}}$ & & \\
\hline \multirow[t]{3}{*}{ Kakamega } & O. coffeae & $4.3^{\mathrm{A}}$ & 6.3 & 0.0588 \\
\hline & S. dorsalis & $2.8^{\mathrm{B}}$ & & \\
\hline & B. phoenicis & $2.8^{\mathrm{B}}$ & & \\
\hline \multirow[t]{3}{*}{ Nyeri } & O. coffeae & $2.3^{\mathrm{A}}$ & 4.0 & 0.1111 \\
\hline & S. dorsalis & $0.0^{\mathrm{A}}$ & & \\
\hline & B. phoenicis & $0.3^{\mathrm{A}}$ & & \\
\hline \multirow[t]{3}{*}{ Kericho } & O. coffeae & $6.8^{\mathrm{A}}$ & 2.5 & 0.2013 \\
\hline & S. dorsalis & $4.0^{\mathrm{A}}$ & & \\
\hline & B. phoenicis & $2.3^{\mathrm{A}}$ & & \\
\hline \multirow[t]{3}{*}{ Kiambu } & O. coffeae & $5.3^{\mathrm{A}}$ & 2.2 & 0.2275 \\
\hline & S. dorsalis & $2.0^{\mathrm{A}}$ & & \\
\hline & B. phoenicis & $5.0^{\mathrm{A}}$ & & \\
\hline
\end{tabular}

Similar superscript letters within each region pest species denote no significance $(p>0.05)$ difference of abundance (Fishers LSD, $\mathrm{F}_{2,8}$ ).

\subsection{Site Leaf Production Levels}

Tea crop production plots were largest in Kiambu (54.2 ha) on corporate farms owned by the small holder farms, while smallest production plots were reported in Imenti North and Kakamega at 0.4 ha (Table 2). Leaf yield was 
highest in Kiambu at 9,167kg followed by Nandi Hills 5,420 kg per year. Lowest leaf yield was scored in Mt. Elgon region followed by Nyeri at 925 and $1,089 \mathrm{~kg}$, respectively. Much of the tea crop was produced in pure crop system besides some areas of Imenti North and Imenti South which included intercropping with bananas, maize, potato and khat production in the same plots.

Table 2. Tea production acreage range (ha), altitude (m), fertilizer input (kg) and subsequent yield $(\mathrm{kg})$ per year at specific site regions in Kenya 2014-2015

\begin{tabular}{lllllll}
\hline Site region* & Altitude $(\mathrm{m})$ & Acreage (ha) & $\begin{array}{l}\text { NPK } \\
(\mathrm{kg})\end{array}$ & $\begin{array}{l}\text { Fertilizer } \\
\mathrm{kg} / \mathrm{ha}\end{array}$ & $\begin{array}{l}\text { Yield } \\
(\mathrm{kg} / \mathrm{ha})\end{array}$ & $\begin{array}{l}\text { Cropping } \\
\text { system }\end{array}$ \\
\hline Imenti North & $1,894 \pm 17$ & $0.4 \pm 0.5$ & $317 \pm 85$ & $793 \pm 25$ & $5,367 \pm 578$ & Bananas, maize \\
Imenti South & $1,789 \pm 24$ & $4.2 \pm 2.0$ & $466 \pm 176$ & $110 \pm 12$ & $7,733 \pm 604$ & Potato, Khat \\
Murang'a & $2,046 \pm 17$ & $0.9 \pm 0.8$ & $320 \pm 168$ & $355 \pm 15$ & $4,100 \pm 872$ & Pure \\
Nakuru & $1,849 \pm 23$ & $1.1 \pm 0.3$ & $200 \pm 100$ & $181 \pm 9$ & $4,000 \pm 515$ & Pure \\
Mt. Elgon & $2,016 \pm 58$ & $0.3 \pm 0.2$ & $125 \pm 35$ & $416 \pm 13$ & $925 \pm 106$ & Pure \\
Nandi Hills & $1,680 \pm 13$ & $3.3 \pm 1.2$ & $355 \pm 29$ & $108 \pm 16$ & $5,420 \pm 512$ & Pure \\
Kakamega & $1,628 \pm 41$ & $2.4 \pm 0.1$ & $366 \pm 115$ & $153 \pm 8$ & $7,067 \pm 290$ & Pure \\
Nyeri & $2,089 \pm 38$ & $1.1 \pm 1.0$ & $283 \pm 124$ & $257 \pm 11$ & $1,089 \pm 221$ & Pure \\
Kericho & $1,925 \pm 10$ & $2.3 \pm 2.1$ & $367 \pm 184$ & $160 \pm 17$ & $1,400 \pm 430$ & Pure \\
Kiambu & $2,371 \pm 65$ & $54.2 \pm 50.9$ & $1,366 \pm 98$ & $25 \pm 4$ & $9,167 \pm 365$ & Pure \\
\hline
\end{tabular}

*Mean parameter ( \pm standard deviation) indicative of value range at the different site regions.

Highest NPK-fertilizer input was reported in Imenti North and Mt. Elgon regions at 793 and $416 \mathrm{~kg} / \mathrm{ha}$, respectively. Lowest fertilizer rate was scored in Kiambu at $25 \mathrm{~kg} / \mathrm{ha}$. Small production plots in eastern and central regions of Imenti North, Imenti South and Murang'a showed the highest fertilizer application, leading to high leaf yield at 5367, 7733 and $4100 \mathrm{~kg} / \mathrm{ha}$, respectively. Similarly, high yield levels were scored from Kakamega, Nandi Hills and Kiambu regions.

\subsection{Identity of Beneficial Organisms}

Sites recording significantly $\left(P<0.0001, F_{11,43}=8.7\right.$ and $\left.P<0.0001, F_{11,45}=7.3\right)$ highest predacious mites (Phytoseiidae Family) were Nyeri and Imenti North at 13.3 and 9.5 individuals per sample during dry season, while for the wet season Nyeri and Imenti North had 14.0 and 12.3, respectively (Table 3). Phytoseiid abundance during the same dry and wet seasons did not significantly differ within most sites. Sites with significant $(P<0.05)$ higher density of phytoseiids during wet season were Mt. Elgon and Kakamega at 6.0 and 3.3 mites per sample. Kericho had significantly $(P<0.05)$ higher density $(6.8)$ of phytoseiids during dry season than the wet period (1.5).

Table 3. Comparable predacious mite density in tea production areas of Kenya during dry and wet seasons in 2014-2015

\begin{tabular}{llllllll}
\hline Year/Period & & & Dry season & Wet season & $\boldsymbol{c v} \%$ & $\boldsymbol{F}$ & $\boldsymbol{P}$ \\
\hline & Site areas & Altitude & No. phytoseiids & No. Phytoseiids & & & \\
$2014 / 2015$ & Imenti South & $1,789.5 \mathrm{bcd}$ & $3.0 \mathrm{c}^{\mathrm{A}}$ & $5.3 \mathrm{bc}^{\mathrm{A}}$ & 35.8 & 0.3 & 0.8361 \\
$2014 / 2015$ & Murang'a & $2,046.0 \mathrm{ab}$ & $6.0 \mathrm{bc}^{\mathrm{A}}$ & $11.5 \mathrm{ab}^{\mathrm{A}}$ & 35.2 & 2.8 & 0.2150 \\
$2014 / 2015$ & Imenti North & $1,894.8 \mathrm{bc}$ & $9.5 \mathrm{ab}^{\mathrm{A}}$ & $12.3 \mathrm{ab}^{\mathrm{A}}$ & 15.1 & 2.5 & 0.2126 \\
$2015 / 2015$ & Mt.Elgon & $2,016.0 \mathrm{ab}$ & $1.8 \mathrm{c}^{\mathrm{B}}$ & $6.0 \mathrm{bc}^{\mathrm{A}}$ & 21.6 & 14.1 & 0.0276 \\
$2014 / 2015$ & Nandi Hills & $1,680.5 \mathrm{~cd}$ & $3.5 \mathrm{c}^{\mathrm{A}}$ & $2.3 \mathrm{c}^{\mathrm{A}}$ & 50.7 & 1.0 & 0.5211 \\
$2015 / 2015$ & Kakamega & $1,628.0 \mathrm{~d}$ & $1.3 \mathrm{c}^{\mathrm{B}}$ & $3.3 \mathrm{c}^{\mathrm{A}}$ & 25.7 & 9.4 & 0.0482 \\
$2014 / 2015$ & Kericho & $2,016.8 \mathrm{ab}$ & $6.8 \mathrm{bc}^{\mathrm{A}}$ & $1.5 \mathrm{c}^{\mathrm{B}}$ & 21.6 & 18.5 & 0.0188 \\
$2014 / 2015$ & Sotik & $2,061.0 \mathrm{ab}$ & $3.8 \mathrm{c}^{\mathrm{A}}$ & $2.8 \mathrm{c}^{\mathrm{A}}$ & 48.8 & 2.4 & 0.2448 \\
$2015 / 2015$ & Nyeri & $1,833.0 \mathrm{bcd}$ & $13.3 \mathrm{a}^{\mathrm{A}}$ & $14.0 \mathrm{a}^{\mathrm{A}}$ & 42.5 & 0.7 & 0.6283 \\
$2015 / 2015$ & Thika & $2,202.3 \mathrm{a}$ & $7.5 \mathrm{bc}^{\mathrm{A}}$ & $7.0 \mathrm{bc}$ & 23.2 & 2.4 & 0.2508 \\
$2015 / 2015$ & Limuru & $2,017.0 \mathrm{ab}$ & $6.8 \mathrm{bc}^{\mathrm{A}}$ & $8.5 \mathrm{abc}$ & 22.4 & 2.2 & 0.2716 \\
$------/ 2015$ & Nakuru & $1,849.3 \mathrm{bcd}$ & - & $6.7 \mathrm{bc}$ & - & - & - \\
& Mean & $1,919.5$ & 5.8 & 6.8 & & & \\
& $F$ & 7.5 & 8.7 & 7.3 & & & \\
\hline
\end{tabular}


Different lower case letters within column denote significant $(P<0.0001)$ difference of altitude and predacious mite density among sites (Fishers Least Significant Difference; GLM PROC). Similarly, different upper case letters across the two seasons mite density indicate significant $(\mathrm{P}<0.05)$ difference at same $5 \%$ level $(d f=1,11)$.

A total of 34 phytoseiid species was identified from all the sites. The most abundant species were Ueckermannseius macrosetosus (130), Amblyseius herbicolus (115), Typhlodromips culmulus (100) and Euseius rhusi (100) in cumulative collections over the period (Fig.1). Thus, U. macrosetosus and A. herbicolus were 23 and $20 \%$ present in the sample fields.

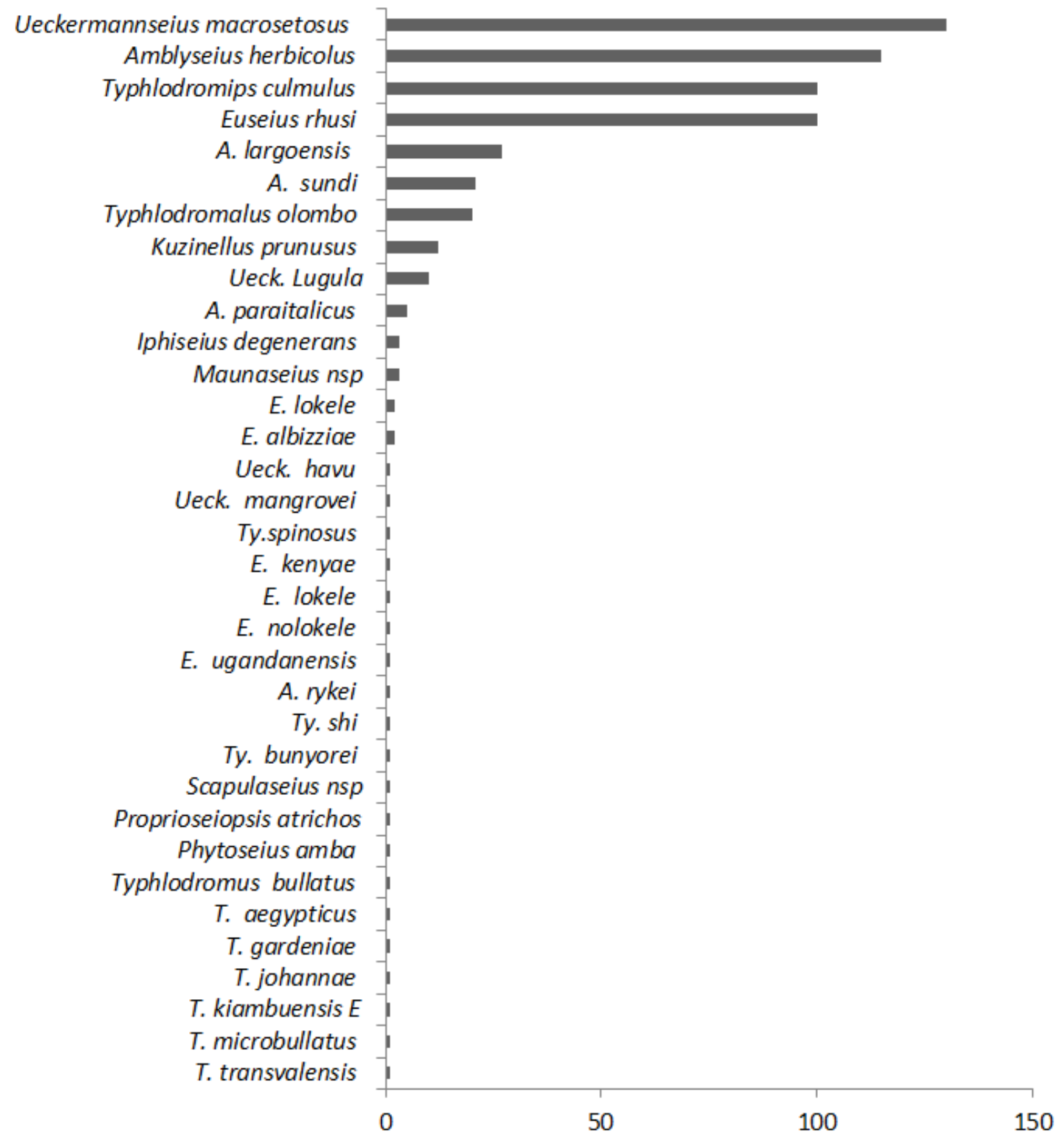

Figure 1. List and abundance of the phytoseiid predatory mites associated with tea plantation in Kenya (No. Sample $=110$; No. individuals $=569$ ).

\subsection{Environment-biological Impact}

Highest leaf yield was observed within the range of 2000m above sea level (Fig.2A). Quantity of fertilizer input per year correlated $\left(R^{2}=0.8691\right)$ with leaf yield at the production sites, as indicated in Figure $2 B$. 


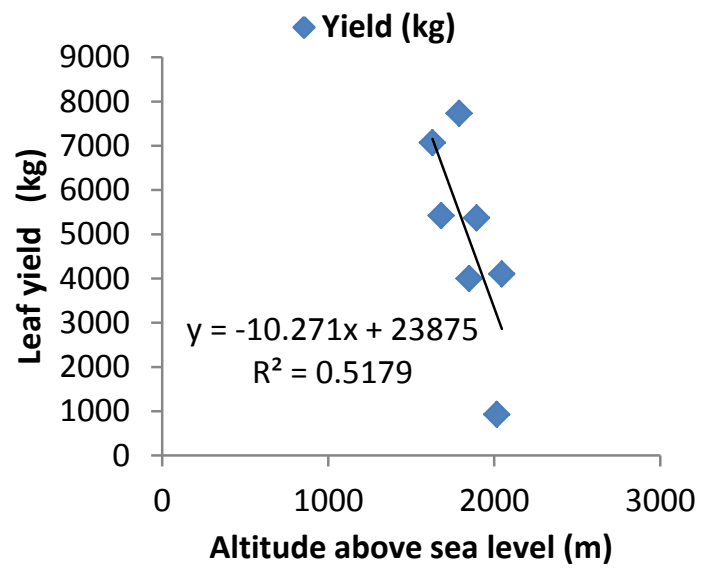

A

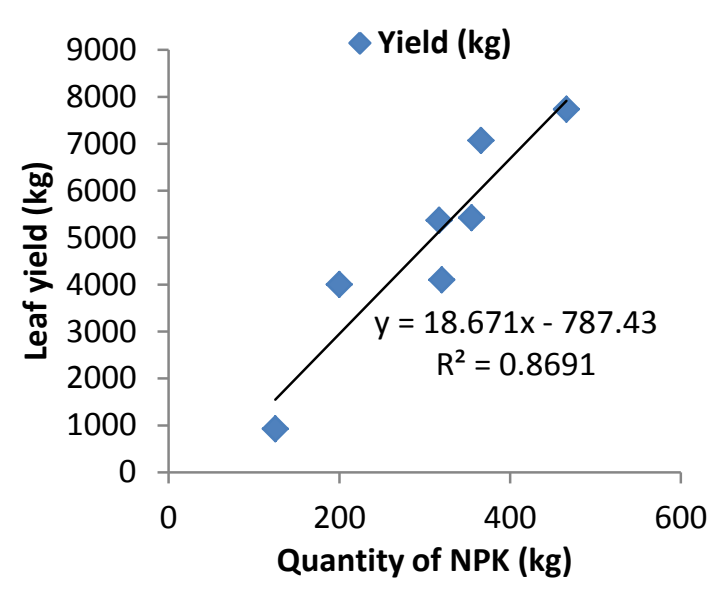

$\mathrm{B}$

Figure 2. Relationship between tea leaf yield and altitude (Fig.2A), and fertilizer (NPK kg) at production sites of Kenya (Fig.2B).

\subsection{Predacious Mites' Positive Impact}

Presence of phytoseiid mites in combination with NPK and high altitude led to strongest significant $(P<0.05$; $\left.\mathrm{R}^{2}=0.9699, F_{2,8}=32.2\right)$ correlation to yield than other variable sets (Table 4). Higher phytoseiid density $(P<$ $\left.0.05 ; \mathrm{R}^{2}=0.6411, F_{2,8}=3.57\right)$ combined with altitude was third in positive impact to yield after altitude combined with NPK fertilizer $\left(P<0.05 ; \mathrm{R} 2=0.8453, F_{2,8}=10.93\right)$.

Table 4. Effects of various variables to tea yield in Kenya production areas in 2014-2015 periods

\begin{tabular}{lllll}
\hline Variable & $\boldsymbol{R}^{2}$ & $\boldsymbol{t}$ & $\boldsymbol{F}$ & $\boldsymbol{P}$ \\
\hline Altitude (m) above sea level & 0.5179 & 2.9 & 5.41 & 0.0682 \\
Fertilizer (NPK) & 0.8613 & 5.6 & 31.04 & 0.0026 \\
Phytoseiid density & 0.0245 & 0.35 & 0.13 & 0.7373 \\
NPK x Phytoseiid density & 0.2119 & 2.2 & 0.54 & 0.6210 \\
Altitude x Phytoseiid density & 0.6411 & 3.20 & 3.57 & 0.1288 \\
Altitude x NPK & 0.8453 & 4.92 & 10.93 & 0.0239 \\
Altitude x NPK x Phytoseiid density & 0.9699 & 10.1 & 32.2 & 0.0088 \\
\hline
\end{tabular}

GLM PROC (SAS) correlation at 5\% level.

\section{Discussion}

The type of tea production system in Kenya remains monoculture in most places probably due to the high value of the crop as major foreign earner of the country. It was only in isolated fields in eastern Kenya highlands of Imenti North and South that inclusion of food crops like bananas, maize, potato and khat were included within tea plant plots or in small production portions. A faunistic survey in Hungary on grape agro ecosystem diversity has shown that phytoseiids presence lead to reduced number of phytophagous mites in vineyards, as it has also been reported on coffee production systems in Kenya (El Banhawy et al. 2009; Szabo et al. 2010).

Results from the present study have shown that the highest leaf yield was within the range of $2000 \mathrm{~m}$ above sea level in Kiambu where highest yield was reported and correlated to NPK fertilizer applied per year. Yield increase is usually a positive response to fertilizer input in most production farms (Jayasinghe \& Toyoda, 2004). Kenya's tea production regions receive high amount of rainfall which could lead to high nutrient leaching and retardant growth of plants, hence need for fertilizer input to sustain leaf yield throughout the year. The results showed that increased NPK-fertilizer input lead to higher leaf yield in small plot holdings in eastern and central Kenya.

Predacious mite abundance was highest in Nyeri at 14.0 and 13.3 mites per sample during the wet season and dry season respectively. Imenti North followed closely at 12.3 and 9.5 mites per sample in the wet season and dry season, respectively. These sites had low red mite density, $O$. coffeae and the yellow thrip $S$. dorsalis, while red crevice mite B. phoenicis was found in few areas and in low numbers. Incidentally, Nyeri is in the central Kenya within the Mt. Kenya region while Imenti North is located in the eastern Kenya hilly areas. Nyeri altitude is 
comparatively higher (> 2000m) while Imenti North is $<1900 \mathrm{~m}$ above sea level. The results showed that most predacious mites were within the $2000 \mathrm{~m}$ range. Conversely, other factors contributed to phytoseiid abundance, most probably being rainfall amount and probably compact plant canopy leading to high humidity regimes to the mite niche ecology (Waage, 2001; Walzer et al., 2007). In the same evaluation Mt. Elgon is within the 2000m altitude range but could only yield 1.8 and 6.0 mites per year during the dry and wet seasons, respectively. Likewise, phytoseiid species distribution and their prey availability and preference was another factor (Waage, 2001). More so, these populations could also be affected by chemical sprays leading to reduced biodiversity of these beneficial agents for pest suppression (Duso et al., 2009). Predacious mite species diversity was 23 from 546 specimens analyzed. The most abundant species were Ueckermannseius macrosetosus (van der Merwe), Amblyseius herbicolus (Chant), Typhlodromips culmulus (van der Merwe) and Euseius rhusi (van der Merwe) presenting over $80 \%$ of the total phytoseiid fauna collected from the farms. The tea canopy was found more compact than that of cassava which was recently found to host 29 species of Phytoseiidae Family where Typhlodromalus aripo (De Leon) and Euseius fustis (Pritchard \& Baker) led by $71 \%$ of the field sample frequency (Molo et al. 2016; Mutisya et al., 2017).

The tea leaf yield status in relation to predacious mites' abundance showed a positive correlation in most of the places sampled. The highest combination of phytoseiid density to yield was observed where altitude-NPK-phytoseiid were highest as inputs followed by altitude-NPK combination. Higher altitude-phytoseiid input provided the third best results to leaf yield level. A pioneer work of ten-year study on agroforestry advantage to increased phytoseiid diversity has been reported in vineyards where tree biodiversity led to higher diversity of phytoseiid within the defined production system (Tixier et al., 2015). Considering the fact that no chemical application is allowed in Kenya's tea production farms other control options are needed. Babu et al. (2008) reported efficacious results of managing $O$. coffeae by application of botanical products like neem. If the option does not work especially within the large commercial farms another option of irrigating the affected farm area would lead to low pest numbers with increased plant vigor and enhanced predacious mite mites due to increased humidity in the agroecosystem (Walzer et al., 2007). Where thrips damage tea, the use of biocides can supplement the predacious mites and preserve the ecosystem with enriched biological diversity where pests are suppressed below economic injury of tea leaf as in other crops (Roy et la. 2014b; Mutisya et al. 2015).

The study results showed that enhanced predacious mite density led to reduced pest status like red spider mites and thrip populations. Further, tea production system of the smallholder farms in Kenya offers high phytoseiid density combined even in high altitude leading to positive impact on leaf yield. In addition, the thick tea canopy and high leaf drop lead to increased soil amendment and high turnover of carbon quantities. These findings translate into an agro ecosystem which is fairly stable and rich in biological diversity of phytoseiid species even at high altitude of $>1900 \mathrm{~m}$ above sea level.

\section{Acknowledgement}

Dr. John Wanyoko formerly of Tea Research Institute is acknowledged for his support and advice on fertility information of tea plants. Ms Judith Silavula of University of Nairobi is also acknowledged for her participation in the 2015 mite collection activities. Mr. David Talam of Tea Research Institute is acknowledged for his efforts to collect data on production areas of tea plants from different Counties of Rift Valley, central and eastern Kenya. The National Commission for Science \&Technology Innovations is acknowledged for funds provision to carry out the project activities. Messrs.' Tom Chepsir and Geoffrey Lagat of Kenya Agricultural and Livestock Research Organization-Tea Research Institute (KALRO-TRI) are also recognized for their part for driving project vehicles taking survey team to various locations in Kenya.

\section{References}

Babu A. K., Perumalsamy, M., Subramaniam, S. R., \& Muraleedharan, N. (2008). Use of neem kernel aqueous extract for the management of red spider mite infesting tea in south India. Journal of Plant Crops, 36(3), 393-397.

El Banhawy, E. M., Irungu, L., \& Mugo, H. (2009). Survey of predacious phytoseiid mites (Acari: Phytoseiidae) inhabiting coffee trees in Kenya with description of some new species. Acarologia, 3-4, 121-137.

El-Banhawy, E. M., \& Knapp, M. (2011). Mites of the family Phytoseiidae Berlese from Kenya (Acari: Mesostigmata). Zootaxa, 2945, 1-176.

Childers, C. C., \& Achor, D. C. (1999). The eriophyid mite complex on Florida citrus (Acari: Eriophyidae and Diptiomiopidae). Proceedings of Florida State Horticultural Society, 112, 79-87. 
Childers, C. C., \& Rodrigues, J. C. V. (2011). An overview of Brevipalpus mites (Acari: Tenuipalpidae) and the plant virus they transmit. Zoosymposia, 6, 180-192.

Duso, C., Kreiter, S., Tixier, M-S., Pozzebon, A., \& Malagnin, V. (2009). Biological control of mites in European vineyards and the impact of natural vegetation. Trends in Acarology, 399-407.

Food and Agriculture Organization (FAO) (2015). World tea production and trade: current and future development. www.fao.org

FAOSTAT. (2016). The top 5 tea producing countries. https.//top5foranything.com/d0ft35cf/tea-producing-countries.

Jayasinghe, J. M. J. K., \& Toyoda, T. (2004). Technical efficiency of organic tea smallholder sector in Sri-Lanka; a stochastic frontier analysis. International Journal of Agriculture Research and Ecology, 3(3-4), 252-265.

Jayakrishnan, T. V., \& Ramani, N. (2015). Reduction of major phytosynthetic pigments induced by Oligonychus coffeae (Nietner) (Acari: Tetranychidae infesting camellia sinensis (L) O. Kuntze. International Journal Research Science, 1, 3947-3950.

Jepson, L. R., Keiffer, H. H., \& Baker, E. W. (1975). Injurious pests to economic plants. University of California Press, Berkeley, p.614.

Majumder, A. B., Bera, B., \& Rajan, A. (2010). Tea statistic: Global Scenario. Journal of Tea Science, 8(1), 121-124.

Muraleedharan, N., Sudarman, D. N. P., \& Selrasundaram, R. (2005). Bio-ecology and management of red spider mite in South India. Proceedings of 2005 International Symposium and Innovation in Tea Science and Sustainable Development in Tea Science Society, pp. 756-766.

Molo, R., Aool, W., Adumo, S., \& Mutisya, D. L. (2016). Integrating cassava varieties and Typhlodromulus aripo to sustain biological control of cassava green mite. African Crop Science Journal, 24, 117-126. http://dx.doi.org/10.4314/acsj.v24i1.13S

Mutisya, D. L., El Banhawy, E. M., Dos Santos, V. V., Kariuki, C. W., Khamala, C. P. M., \& Tixier, M-S. (2017) Predatory phytoseiid mites associated with cassava in Kenya, identification key and molecular diagnosis (Acari: Phyotoseiidae). Acarologia, 57(3), 541-554. http://dx.doi.org/10.24349/acarologia/20174172

Mutisya, D. L., El-Banhawy, E. M., Khamala, C. P. M., \& Kariuki, C. W. (2015). Management of cassava green mite Mononychellus progresivus (Acari: Tetranychidae) in different agro-ecological zones of Kenya. Systematic and Applied Acarology, 20(1), 39-50. https://doi.org/10.11158/saa.20.1.5

Szabo, A., Koradi, I., Tempfli, B., \& Penzes, B. (2010). Phytoseiid mites in the Hungarian vineyard. Acta Phytopathologica et Entomolica Hungarica, 45(2), 337-347. http://dx.doi: 556/Aphyt.45.2010.2.11.

Roy, S., Muraleedharan, N., \& Mukhopadhyay, P. (2014b). The red spider mite, Oligonychus coffeae (Acari: Tetranychidae): its status, biology, ecology and management in tea plantations. Experimental and Applied Acarology, 63(4), 431-463. https://doi.org/10.1007/s10493-014-9800-4

Roy, S., Chakraborti, D., \& Das, S. (2014a). Effectiveness of garlic lectin on red spider mite of tea. Journal of Plant Interaction, 3(3), 157-162. https://doi.org/10.1080/17429140701754195

Tixier, M-S, Arnaud, A., Douin, M., \& Kreiter, S. (2015). Effects of agroforestry on Phytoseiidae communities (Acari: Mesostigmata) in vineyards. A synthesis of a 10-year period of observation. Acarologia, 55(4), 361-375. https://doi.org/10.1051/acarologia/20152182

Waage, J. K. (2001). Indirect ecological effects in biological control: The challenge and the opportunity. In: Wasiberg, E., Scott, J. K., Quimby, P. C. (eds.). Evaluating effects of biological control. On: Proceedings of the First Integrated Symposium on biological control. CABI Publishing, Oxford. UK. pp 1-12. https://doi.org/10.1079/9780851994536.0001

Walzer, A., Castagnoli, M., Simoni, S., Liguori, M., Palevsk, E., \& Schausberger, P. (2007). Intraspecific variation in humidity susceptibility of the predatory mite Neoseiulus californicus: survival, development and reproduction. Biological Control, 41, 42-52. https://doi.org/10.1016/j.biocontrol.2006.11.012

\section{Copyrights}

Copyright for this article is retained by the author(s), with first publication rights granted to the journal.

This is an open-access article distributed under the terms and conditions of the Creative Commons Attribution license (http://creativecommons.org/licenses/by/3.0/). 